Надія Височіна, доктор наук з фізичного виховання і спорту, старший дослідник

Навчально-науковий інститут фізичної культури та спортивно-оздоровчих технологій Національного університету оборони України імені Івана Черняховського ORCID ID 0000-0001-6098-9699

Василь Білошицький,

Навчально-науковий інститут фізичної культури та спортивно-оздоровчих технологій Національного університету оборони України імені Івана Черняховського ORCID ID 0000-0001-6083-2579

Ольга Малахова,

Навчально-науковий інститут фізичної культури та спортивно-оздоровчих технологій Національного університету оборони України імені Івана Черняховського

ORCID ID 0000-0002-9227-9234

DOI: $10.33099 / 2617-1775 / 2021-01 / 43-55$

\title{
ФІЗИЧНА ПІДГОТОВКА І СПОРТ У ЗБРОЙНИХ СИЛАХ УКРАЇНИ: ПРОБЛЕМИ ТА ПЕРСПЕКТИВИ
}

У статті розглянуто актуальні проблеми фізичної підготовки і спорту у Збройних Силах України. Проаналізовано причини та фактори, щуо чинять негативний вплив на ефективність організації та управління процесом фізичної підготовки військовослужбовців. Показано шляхи вирішення проблем.

Фізична підготовка військовослужбовців $є$ невід'ємною складовою частиною загальної системи виховання і навчання особового складу Збройних Сил Украӥни та інших військових формувань сектора безпеки і оборони, утворених відповідно до законів Украйни, та спрямована на забезпечення фізичної готовності особового складу до професійної діяльності.

У зв'язку з ичи особливої актуальності набуває питання ефективної організації централізованої підготовки кадрів з фізичної підготовки і спорту для структур сектору безпеки і оборони України. Для вирімення цієєї проблеми Міністерством оборони Украӥни проводиться системна робота щзодо вдосконалення військової освіти для ї̈ адаптації до системи підготовки країн-членів НАТО і ЄС. Вивчення досвіду ичих країн свідчить про тенденцію изентралізації підготовки фахівців у сфері фізичної підготовки $і$ спорту для Збройних Сил, правоохоронних органів і поєднання процесу підготовки кадрів з організачією наукових досліджень.

Існуюча система організаиії фізичної підготовки та спорту у Збройних Силах Украӥни не повною мірою забезпечує належний рівень фрізичної готовності військовослужбовців до виконання навчально-бойових завдань, недостатньо спонукає військовослужбовиів до занять фізичною культурою $і$ спортом, підтримання здорового способу життя, щзо негативно впливає на якість освітнього процесу підготовки курсантів $i$ слухачів вищих військових навчальних закладів та на ефективність управління процесом фізичного вдосконалення військовослужбовців. Тому, впровадження запропонованих рекомендацій дозволить оптимізувати процес фізичної підготовки військовослужбовців. 

життя.

Ключові слова: Фізична підготовка і спорт, Збройні Сили Украйни,здоровий спосіб

Постановка проблеми. Фізична підготовка військовослужбовців $\epsilon$ невід'ємною складовою загальної системи виховання і навчання особового складу Збройних Сил України та інших військових формувань сектора безпеки i оборони, утворених відповідно до законів України, та спрямована на забезпечення фізичної готовності особового складу до професійної діяльності.

У зв’язку з цим особливої актуальності набуває питання ефективної організації централізованої підготовки кадрів з фізичної підготовки і спорту для структур сектору безпеки і оборони України. Для вирішення цієї проблеми Міністерством оборони України проводиться системна робота щодо вдосконалення військової освіти для їі адаптації до системи підготовки країнчленів НАТО і ЄС. Вивчення досвіду цих країн свідчить про тенденцію централізації підготовки фахівців у сфері фізичної підготовки і спорту для Збройних Сил, правоохоронних органів і поєднання процесу підготовки кадрів з організацією наукових досліджень.

Аналіз останніх досліджень і публікацій свідчить про те, що сьогодні існує багато наукових праць, присвячених проблемі фізичної підготовки військовослужбовців: В. І. Баркова, Н. Б. Вербина, С. І. Глазунова, С. М. Жембровського, О. В. Петрачкова [1], Ю. С. Фіногенова [2], Н. Б. Вербина та співавторів [3], Д. В. Погребняка [4] та інших. До того ж це питання детально досліджено фахівцями у зарубіжних виданнях: N. Vysochina, O. Fedorenko, V. Vorona [5], S. Romanchuk [6], Y. Sergienko, A. Andreianov [7]. Деякі науковці приділяли увагу окремим питанням процесу фізичного вдосконалення: Н. Височіна, Л. Гуніна, О. Хацаюк, В. Томашевський, А. Титович [8] та О. M. Kokun [9] досліджували аспекти професійної компетентності фахівців, F. Campos, M. Marques, S. Silva, F. Martins, V. Simoes, S. Franco [10] вивчали гендерні особливості спортивної діяльності, D. Hortigüela, J. Fernández-Río, A. Pérez-Pueyo [11] розглядали педагогічні особливості фізичного виховання, G. Ilnytska etc. [12] вивчали вплив оздоровчої фізкультури, В. І. Свистун та В. А. Шемчук [13] досліджували наукову складову цього процесу. Проте вирішення питань, пов'язаних 3 сучасними проблемами фізичної підготовки військовослужбовців потребує додаткового розгляду, що зумовило вибір даної теми дослідження.

Мета дослідження. Виявити і проаналізувати основні проблеми фізичної підготовки і спорту в Збройних Силах України.

Методи дослідження: аналіз і узагальнення даних науково-методичної літератури та мережі Інтернет, експертне опитування, розрахунок коефіцієнта конкордації Кендалла.

Результати. Реформування системи фізичної підготовки i спорту зумовлено наявністю причин i факторів, які негативно впливають на ефективність організації та управління процесом фізичної підготовки військовослужбовців Збройних Сил України.

У зв’язку з цим однією з актуальних проблем, що потребують вирішення, стало вдосконалення керівних документів, що регламентують функціонування 
системи фізичної підготовки і спорту в Міністерстві оборони України та Збройних Силах України з метою реалізації вимог оновлених нормативноправових актів з питань функціонування та розвитку Збройних Сил України в сучасних умовах.

Не менш важливим є розгляд питання щодо визначення кількості і якості фахівців фізичної підготовки і спорту для забезпечення організації процесу фізичної підготовки і проведення спортивних заходів 3 особовим складом у Збройних Силах України.

Також варто звернути увагу на відсутність централізованої системи управління фізичною підготовкою i спортом, порушення принципу централізації. Наслідком цього стала діяльність паралельно діючих структур різного рівня підпорядкування. Це не забезпечує необхідного функціонування системи фізичної підготовки і спорту.

Потребує доопрацювання система організації науково-дослідницької роботи в сфері фізичної підготовки і спорту. Необхідна розробка і наукове обгрунтування комплексу (стандартів) інформативних фізичних і спеціальних вправ (прийомів) для кожної категорії військовослужбовців 3 метою визначення рівня їх фізичної готовності до виконання бойових завдань за призначенням. На підставі отриманих показників слід оновлювати відповідні документи.

При цьому існує необхідність вдосконалення організації фізичної підготовки в системі бойової підготовки у військах (силах) відповідно до вимог концептуальних змін в організації бойового навчання і обліку набутого досвіду ведення бойових дій в зоні операції Об'єднаних сил і досягнення сумісності 3 програмою фізичної підготовки провідних країн світу.

Наступна актуальна проблема - це вдосконалення системи перепідготовки, підготовки і підвищення кваліфікації кадрів 3 фізичної підготовки і спорту. 3 огляду на євроінтеграційні процеси, які проходять в суспільстві, вступ в силу законодавчих актів щодо реформування та розвитку Збройних Сил України, актуальним стає питання підготовки кадрів з фізичної підготовки і спорту для структур, що входять в сектор безпеки і оборони України. Фізична підготовка є одним з основних предметів бойової підготовки військ і безпосередньо впливає на рівень боєздатності Збройних Сил України, військових формувань і правоохоронних органів. Для вирішення проблеми підготовки висококваліфікованих фахівців фізичної підготовки і спорту для Збройних Сил України, інших військових формувань та правоохоронних органів 2 січня 2018 у складі Національного університету оборони України імені Івана Черняховського створено Навчально-науковий інститут фізичної культури і спортивно-оздоровчих технологій (далі Інститут) [14]. Основне завдання Інституту полягає в організації системи цілісної багаторівневої (безперервної) підготовки військових фахівців фізичної підготовки і спорту на тактичному і оперативно-тактичному рівні.

У 2018 році в Інституті проведено ліцензування освітньої діяльності за ступенем вищої освіти бакалавр за спеціальністю “Фізична культура і спорт", а у 2019 році за ступенем магістр. Розпочато підготовку магістрів оперативнотактичного рівня за спеціальністю “Забезпечення військ (сил)” спеціалізації 
“Організація фізичної підготовки і спорту у військах (силах)”. На базі Інституту функціонують курси підвищення кваліфікації фахівців з питань організації та проведення фізичної підготовки у військах. Крім того, в Інституті здійснюється підготовка (перепідготовка) та підвищення кваліфікації фахівців водолазної справи.

В червні 2020 року проведена державна атестація курсантів 4 курсу за спеціальністю 017 “Фізична культура і спорт”. Результати складання комплексного екзамену та захисту кваліфікаційних робіт показують, що підготовка курсантів організована та відповідає вимогам замовників на підготовку військових фахівців фізичної підготовки і спорту. Проведено перший випуск фахівців фізичної підготовки і спорту тактичного рівня.

Не менш важливим $є$ наявність недостатньої рухової активності військовослужбовців, що пов'язано з їх функціональними обов'язками. Рухова активність - необхідна умова нормального розвитку i функціонування організму. Вона не просто корисна, а життєво необхідна. Значна частина військовослужбовців веде малорухливий спосіб життя, тому що вони працюють в управліннях та штабах. При нестачі рухової активності організм поступово втрачає життєві сили, стає чутливим до негативного впливу зовнішніх несприятливих факторів. При цьому сучасний спосіб життя військовослужбовців супроводжується високим рівнем психоемоційного стресу. Для корекції цього стану потрібно підтримувати фізичну активність i використовувати спортивно-оздоровчі технології, що вимагає певних вольових зусиль $[15,16]$. Така проблема пов'язана 3 тим, що значна кількість військовослужбовців не мають можливості відвідувати спортивні об'єкти через відсутність часу, в зв'язку з великою робочою навантаженням, що викликано нестачею кадрів в підрозділі. Тому ми пропонуємо на початку кожного робочого дня, протягом 20-30 хвилин, проводити фізичну розминку і вводити протягом робочого дня фізкультурні паузи, що сприятиме зміцненню здоров'я i підвищенню працездатності військовослужбовців.

Також, в рамках співпраці і для пропаганди здорового способу життя, доцільно організувати надання працівникам абонементів в спортивні установи неподалік від місця проживання військовослужбовця, або біля місця служби (якщо на території відсутні спортивні об'єкти або вони не в змозі охопити весь особовий склад, який значиться в штаті), як в робочі дні так і в вихідні. Таким чином військовослужбовець вибере зручний час для занять спортом i, тим самим, збільшить свою рухову активність.

Привертає увагу відсутність науково обгрунтованої мотиваційної системи залучення військовослужбовців до занять фізичною підготовкою і спортом та заохочення за спортивні досягнення, що може бути важливим засобом виховання і зміцнення військової дисципліни, сприяти прагненню до перемог $\mathrm{i}$ роботі над собою. Система заохочення повинна включати систему матеріального i додаткового заохочення. Для забезпечення матеріального заохочення використовують винагороду, що являє собою матеріальний дохід, який складається з двох частин (базової і преміальної). 
Матеріальна винагорода має бути конкурентоспроможною. Базовий оклад - відносно постійна частина матеріальної винагороди співробітника, яка переглядається не частіше, ніж один раз на півроку або при зміні посади.

Регулярні систематичні заохочення спонукатимуть військовослужбовців підвищувати свої фізичні показники та постійно працювати над їх вдосконаленням.

Крім того, потребує удосконалення навчальна та матеріально-технічна база фізичної підготовки і спорту. Навчальна і матеріально-технічна база вищих військових навчальних закладів та військових навчальних підрозділів включає в себе комплекс навчальних, матеріальних і технічних засобів і обладнаних навчальних об'єктів (місцевості, полігонів), призначених для забезпечення підготовки курсантів (ад'юнктів, докторантів, слухачів, студентів, іноземних громадян, які навчаються відповідно до контрактів), угод і програм підготовки (перепідготовки) фахівців іноземних держав за визначеним переліком спеціальностей та спеціалізацій, підготовки військових фахівців відповідно до навчальних планів і програм навчальних дисциплін, а також для підготовки науково-педагогічних кадрів та проведення наукових досліджень.

Можливості військових частин, вищих військових навчальних закладів та військових навчальних підрозділів визначаються станом їх матеріальнотехнічної бази, рівень розвитку якої зумовлює масштаби підготовки фахівців, безпосередньо впливає на їх якість і на результативність наукових досліджень. Розвиток вищих військових навчальних закладів та військових навчальних підрозділів передбачає, перш за все, зміцнення матеріальної бази для виконання вимог, що пред'являються до них.

Серед перерахованих проблем не останнє місце займає необхідність вдосконалення системи інформаційного забезпечення функціонування фізичної підготовки і спорту в Міністерстві оборони України та Збройних Силах України [8]. Формування сучасного інформаційного забезпечення фізичного виховання військовослужбовців нерозривно пов'язане 3 інформаційними технологіями, проектування і застосування яких має забезпечити:

- придбання знань і рухових умінь;

• розвиток фізичних якостей військовослужбовців;

- зміцнення здоров'я;

• сприяння вдосконаленню організаційних форм занять і підвищенню ефективності навчально-тренувальної діяльності, повному використанню освітнього потенціалу фізичної культури;

• оптимізації зворотного зв'язку в тренерському управлінні;

- створення міцної мотиваційної основи навчання і фізичного розвитку за допомогою інтерактивних форм подання навчальної інформації, об'єктивної оцінки та аналізу результатів навчально-тренувальної діяльності.

Відповідно до наказу Національного агентства із забезпечення якості вищої освіти від 5 травня 2020 року № 732-Е у Національному університеті оборони України імені Івана Черняховського з 13 по 15 травня 2020 року була проведена акредитаційна експертиза із використанням технічних засобів відеозв’язку за спеціальністю “017 Фізична культура і спорт” освітньої 
програми першого (бакалаврського) рівня вищої освіти. За результатами експертизи прийнято рішення щодо акредитації освітньої програми на п'ять років (протокол № 12 (29) Національного агентства із забезпечення якості вищої освіти від 26.06.2020 р.).

Серед інших проблем пильну увагу привертає потреба в реорганізації спортивних установ Міністерства оборони України і їх співпраця з місцевими органами виконавчої влади, громадськими організаціями фізкультурноспортивної спрямованості і військовими частинами.

Проаналізувавши базу всіх військових навчальних закладів, частин, установ, ми бачимо, що не всі з них мають необхідні спортивні об'єкти, такі як стадіон, басейн, майданчики i зали. Шляхом вирішення цієї проблеми $\epsilon$ співпраця 3 місцевими органами виконавчої влади, школами, інтернатами, ліцеями і громадськими організаціями фізкультурно-спортивної спрямованості. Це можливо реалізувати 3 залученням їх бази, що вирішить проблему відсутності того чи іншого об'єкта.

Для виявлення значущості вищевказаних проблем нами було проведено опитування експертів, у якому взяли участь 210 військовослужбовців 3 Сухопутних військ (СВ), Військово-Морських Сил (ВМС), Повітряних Сил (ПС), Десантно-штурмових військ (ДШВ) і Сил спеціальних операцій ( ССО) Збройних Сил України. Опитування проводилося у вигляді анонімного анкетування протягом двох тижнів. Опитуваним було запропоновано дати оцінку за шкалою від 0 до 100 балів 3 найбільш актуальних проблемних напрямів, стосовно фізичної культури (табл. 1).

Таблиия 1

Результати експертної оцінки проблем фізичної культури і спорту в Збройних Силах України (\%)

\begin{tabular}{|c|c|c|c|c|c|c|c|}
\hline $\begin{array}{c}\text { Види та } \\
\text { роди } \\
\text { ЗСУ }\end{array}$ & $\begin{array}{c}\text { Кількість } \\
\text { респондент } \\
\text { ів }\end{array}$ & $\begin{array}{c}\text { Якість } \\
\text { спортивн } \\
\text { о-масових } \\
\text { заходів }\end{array}$ & $\begin{array}{c}\text { Додаткові } \\
\text { заняття } \\
\text { (секції) під } \\
\text { керівництв } \\
\text { ом фахівця } \\
\end{array}$ & $\begin{array}{c}\text { Наявність } \\
\text { фізкультурн } \\
\text { их пауз під } \\
\text { час робочого } \\
\text { дня } \\
\end{array}$ & $\begin{array}{l}\text { Забезпечен } \\
\text { ня фізичної } \\
\text { підготовки }\end{array}$ & $\begin{array}{c}\text { Стан } \\
\text { спортивни } \\
\text { х споруд } \\
\text { (майданчи } \\
\text { ків) } \\
\end{array}$ & $\begin{array}{c}\text { Коефіці } \\
\text { снт } \\
\text { конкор } \\
\text { дації }\end{array}$ \\
\hline $\begin{array}{l}\text { Сухопутн } \\
\text { i війська }\end{array}$ & 69 & $30 \pm 2,4$ & $49 \pm 3,1$ & $47 \pm 0,7$ & $71 \pm 6,3$ & $72 \pm 4,6$ & 0,71 \\
\hline $\begin{array}{l}\text { Військово } \\
\text {-Морські } \\
\text { Сили } \\
\end{array}$ & 56 & $20 \pm 2,7$ & $35 \pm 4,8$ & $46 \pm 3,4$ & $68 \pm 7,2$ & $63 \pm 7,6$ & 0,66 \\
\hline $\begin{array}{l}\text { Повітряні } \\
\text { Сили }\end{array}$ & 43 & $15 \pm 3,4$ & $20 \pm 3,9$ & $43 \pm 4,1$ & $64 \pm 3,9$ & $55 \pm 5,3$ & 0,74 \\
\hline $\begin{array}{l}\text { Десантно- } \\
\text { штурмові } \\
\text { війська } \\
\end{array}$ & 27 & $28 \pm 1,6$ & $48 \pm 7,2$ & $78 \pm 1,5$ & $78 \pm 2,1$ & $41 \pm 3,2$ & 0,76 \\
\hline $\begin{array}{l}\text { Сили } \\
\text { спеціальн } \\
\text { их } \\
\text { операцій } \\
\end{array}$ & 15 & $80 \pm 0,8$ & $75 \pm 5,4$ & $92 \pm 0,6$ & $82 \pm 1,1$ & $58 \pm 0,3$ & 0,83 \\
\hline
\end{tabular}

Note. $\mathrm{p}<0,05$

Для визначення узгодженості думок експертів i підтвердження правильності гіпотези про те, що експерти роблять відносно точні вимірювання, використовували коефіцієнт конкордації Кендалла. Виявлено, що 
думки більшості експертів збігаються, що підтверджується високими показниками коефіцієнта конкордації.

Аналіз отриманого матеріалу, дозволив виявити, що найнижчі показники були отримані за шкалою "Якість спортивно-масових заходів (більшість індивідуальних показників не перевищує 50 балів). Це свідчить про те, що даному питанню приділяється недостатньо уваги, що необхідно враховувати як при організації спортивних заходів, так і в підготовці фахівців.

Також викликають інтерес дані, що відображають “Додаткові заняття (секції) під керівництвом фахівця. Більшість опитаних зійшлися на думці, що це пов'язано з браком фахівців за спеціальністю “Фізичне виховання і спорт в Збройних Силах України”. До 2018 року не було створено жодного інституту фізичної культури, який вирішив би проблему укомплектування фахівцями Збройних Сил України та інших військових формувань сектора безпеки i оборони, оскільки існуючі кафедри не вирішували питання нестачі кваліфікованих кадрів.

Потребує вдосконалення напрям “Наявність фізкультурних пауз під час робочого дня”. Особливо помітно ця проблема впливає в навчальних закладах, де під час перерви між заняттями офіцери (курсанти) не збільшують свою рухову активність, а, навпаки, у багатьох з них спостерігається залежність від гаджетів.

Оцінка респондентами стану забезпеченості фізичної підготовки (матеріально-технічне, фінансове, медичне, агітаційне, правове) вказує на те, що більшість військовослужбовців задоволені існуючим станом, але деякі $з$ них відзначили, що фінансова забезпеченість розподіляється не рівномірно, так як на кожну військову частину або навчальний заклад надходять різні суми коштів.

За шкалою “Стан спортивних споруд (майданчиків)", були отримані середні показники, але в цілому переважає позитивна динаміка у вирішенні даної проблеми, оскільки останнім часом постійно здійснюється вдосконалення спортивної бази ЗСУ.

Ще однією важливою проблемою є боротьба 3 поширеною шкідливою звичкою - курінням. Результати опитування 3 цього питання представлені на рисунку 1 i вказують на те, що в значній мірі цей фактор проявляється у представників Повітряних Сил (82\%), Військово-Морських Сил (71\%) i Сухопутних військ (68\%). Незважаючи на те, що куріння деструктивно впливає на стан здоров'я, більшість військовослужбовців не планують відмовлятися від цієї звички. На жаль, попередження Міністерства охорони здоров’я, статистика онкологічних і серцево-судинних захворювань, погіршення власного здоров'я не є переконливими факторами для курців. 


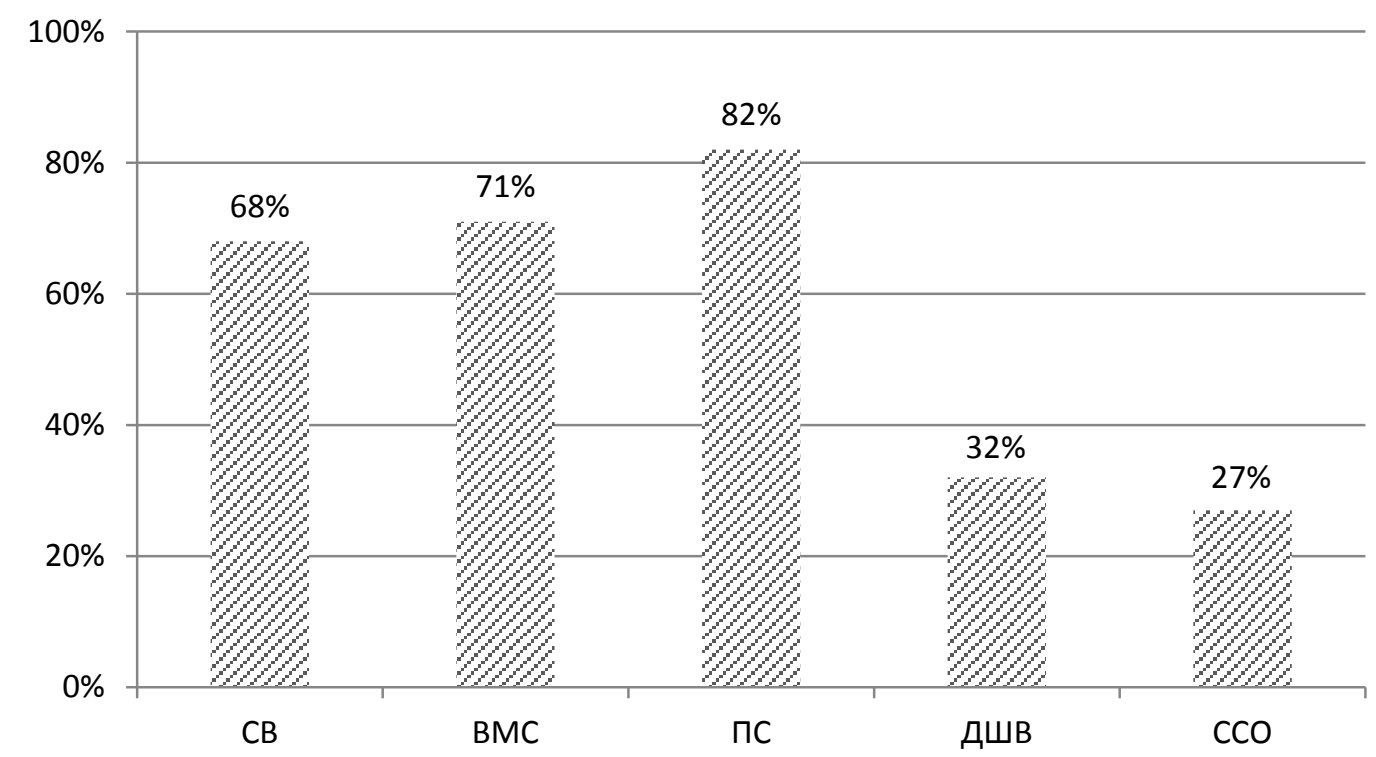

\section{Рис. 1. Наявність курців в колективі}

Примітка: СВ - Сухопутні війська; ВМС - Військово-Морські Сили; ПС Повітряні сили; ДШВ - Десантно-штурмові війська; ССО - Сили спеціальних операцій.

Значна розбіжність показників спостерігається у відповідях на питання “Наявність військовослужбовців з надмірною вагою” (рис. 2). Сидяча робота, неправильне харчування, малорухливий спосіб життя як під час службового робочого дня, так і в позаслужбовий час - все це негативно впливає, насамперед, на стан здоров'я і на бойову готовність військовослужбовця. Більшість 3 тих, хто має надлишкову вагу, навіть не замислювалися над тим, що надмірна вага $є$ причиною виникнення багатьох захворювань.

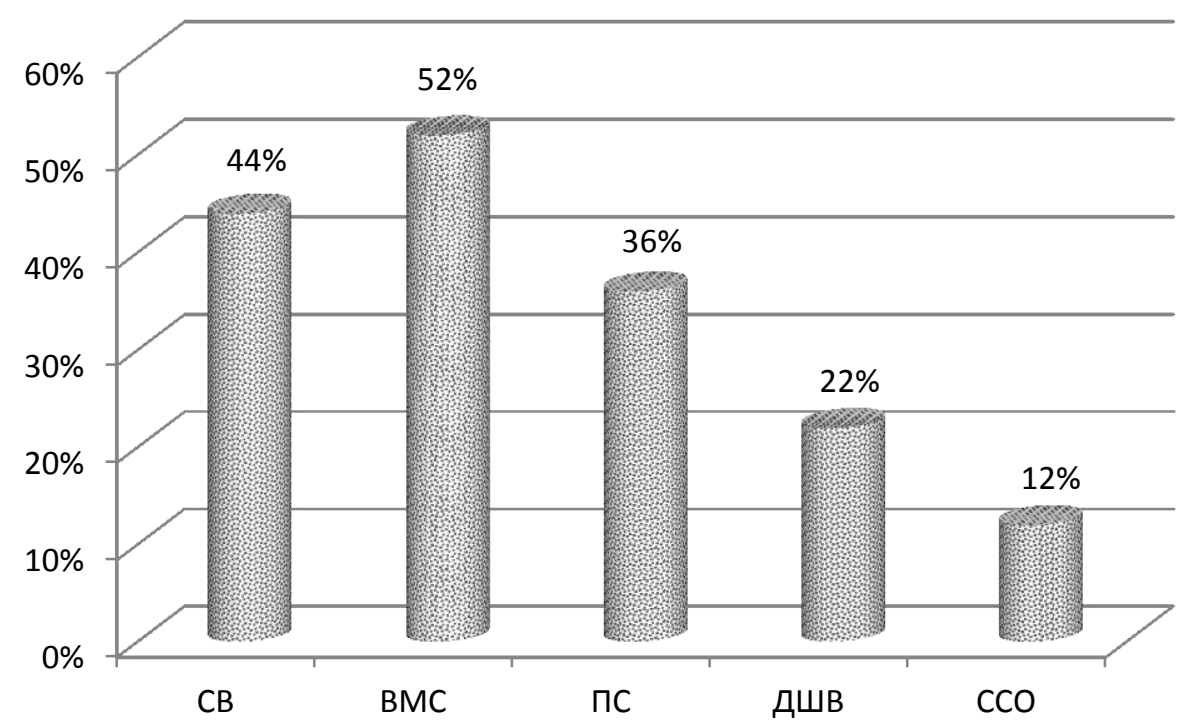

Рис. 2. Наявність військовослужбовців з надмірною вагою

Примітка: CВ - Сухопутні війська; ВМС - Військово-Морські Сили; ПС Повітряні сили; ДШВ - Десантно-штурмові війська; $\mathrm{CCO}$ - Сили спеціальних операцій. 
Результати опитування свідчать, що існуюча система організації фізичної підготовки та спорту у Збройних Силах України та інших військових формуваннях сектора безпеки і оборони хоч і має позитивну динаміку, але в цілому потребує вдосконалення з орієнтацією на міжнародні стандарти фізичної підготовки військовослужбовців.

Висновки i перспективи подальших досліджень. 3 урахуванням перерахованих вище факторів, існуюча система організації фізичної підготовки та спорту у Збройних Силах України не повною мірою забезпечує належний рівень фізичної готовності військовослужбовців до виконання навчальнобойових завдань, недостатньо спонукає військовослужбовців до занять фізичною культурою і спортом, підтримання здорового способу життя, що негативно впливає на якість освітнього процесу підготовки курсантів і слухачів вищих військових навчальних закладів та на ефективність управління процесом фізичного вдосконалення військовослужбовців. Тому, впровадження запропонованих рекомендацій і пропозицій дозволить оптимізувати процес фізичної підготовки військовослужбовців.

\section{ЛІТЕРАТУРА}

1. Барков В. І. Забезпечення фізичної підготовки військовослужбовців: навч. посібн. / В. І. Барков, Н. Б. Вербин, С. І. Глазунов, С. М. Жембровський, О. В. Петрачков. - К. : НУOУ, 2016. $-88 \mathrm{c}$.

2. Фізичне виховання, спеціальна фізична підготовка та спорт: підручник / колектив авторів; за ред. Ю. С. Фіногенова. - К. : НУОУ ім. Івана Черняховського, 2014. - 468 с.

3. Вербин Н. Б. Витривалість військовослужбовців та методика ії розвитку. Навч.метод. посібник / Н. Б. Вербин, Н. Л. Височіна, С. Ф. Костів, О. В. Петрачков, В. І. Свистун, В. А. Шемчук. - К. : НУОУ, 2020. - 120 c.

4. Погребняк Д. В. Організаційно-педагогічні умови розвитку фахової компетентності начальників фізичної підготовки і спорту військових частин Збройних Сил України в системі післядипломної освіти / Д. В. Погребняк. - Вісник Житомирського державного університету імені Івана Франка. Педагогічні науки, 2018. Вип. 4. - С. 160-165.

5. Vysochina, N., Fedorenko, O., Vorona, V. (2019). Problems of physical training and sports in the Armed Forces of Ukraine. Black sea scientific journal of academic research, 46 (3), 49.

6. Romanchuk, S. (2015). Self-educational technologies of the commanders of cadets units of higher military educational institutionsin the field of physical training and sports. Journal of Physical Education and Sport, 15 (3), 498-501.

7. Sergienko, Y., Andreianov, A. (2013). Model of professional readiness of students of higher military schools of the Armed Forces of Ukraine. Physical Education of Students, 6, 6672 .

8. Височіна Н. Вдосконалення професійних компетентностей офіцерів-фахівців фізичної підготовки і спорту у напрямі використання сучасних інтерактивних педагогічних технологій / Н. Височіна, Л. Гуніна, О. Хацаюк, В. Томашевський, А. Титович. - Київ : Військова освіта, 2020. № 2. - С. 76-88.

9. Kokun, O. M. (2012). Professional orientation and competence of future professionals with a "person-person" occupational type. Social Welfare. Interdisciplinary Approach, 2 (2), 36-47.

10. Campos, F., Marques, M., Silva, S., Martins, F., Simoes, V., Franco, S. (2017). Physical self-description and sport participation, by gender, of university students. Journal of Physical Education and Sport, 17 (1), 207-211. DOI:10.7752/jpes.2017.01031 
11. Hortigüela, D., Fernández-Río, J., Pérez-Pueyo, A. (2016). Long-term effects of the pedagogical approach on the perceptions of physical education by students and teachers. Journal of Physical Education and Sport, 16 (4), 1326-1333. DOI:10.7752/jpes.2016.04210

12. Ilnytska, G., Kozina, Z., Kaвatska, O., Kostiukevych, V., Goncharenko, V., Bazilyuk, T., Al-rawashdeh, A. (2016). Impact of the combined use of health-improving fitness methods ("Pilates" and "Bodyflex") on the level of functional and psychophysiological capabilities of students. Journal of Physical Education and Sport, 16 (1), 234-240. DOI: 10.7752/jpes.2016.01037

13. Свистун В. I. Науково-дослідна лабораторія як організатор і координатор інноваційного наукового середовища вищого військового навчального закладу / В. І. Свистун, В. А. Шемчук. - Вісник Житомирського державного університету імені Івана Франка. Педагогічні науки, 2018. Вип. 4. - С. 182-187.

14. Petrachkov, O., Vysochina, N. (2019). The establishment of the Educational and scientific institute of physical culture and sports and health technologies of the National Defence University of Ukraine named after Ivan Chernyakhovskyi. Sporto mokslas, 1, 76-78. DOI: https://doi.org/10.15823/sm.2019.95

15. Костів С. Ф. Емоційно-вольова стійкість майбутніх військових фахівців / С. Ф. Костів. - Київ: Військова освіта. Київ, 2017. № 2 (36). - С. 107-116.

16. Vysochina, N., Vorobiova, A. (2017). Goal-setting in sport and the algorithm of its realization. Ştiinţa culturii fizice, 28/2, 108-112.

\section{REFERENCES}

1. Barkov, V. I., Verbin, N. B., Glazunov, S. I., Zhembrovsky, S. M., Petrachkov, O. V. (2016). Zabezpechennia fizychnoi pidhotovky viiskovosluzhbovtsiv: navch. posibn [Provision of physical training of servicemen: textbook]. Kiev, NUOU, 88.

2. Finogenov, Yu. S. (2014). Fizychne vykhovannia, spetsialna fizychna pidhotovka ta sport: pidruchnyk / kolektyv avtoriv; za red. Yu.S. Finohenova [Physical education, special physical training and sports: textbook]. Kiev, NUOU, 468.

3. Verbin, N. B., Vysochina, N. L., Kostiv, S. F., Petrachkov, O. V., Svystun, V. I., Shemchuk, V. A. (2020). Vytryvalist viiskovosluzhbovtsiv ta metodyka yii rozvytku. Navch.metod. posibnyk [Endurance of servicemen and methods of its development. Teaching method manual]. Kiev, NUOU, 120.

4. Pohrebniak, D. V. (2018). Orhanizatsiino-pedahohichni umovy rozvytku fakhovoi kompetentnosti nachalnykiv fizychnoi pidhotovky i sportu viiskovykh chastyn Zbroinykh Syl Ukrainy v systemi pisliadyplomnoi osvity [Organizational and pedagogical conditions of special competence development of heads of physical training and sports of military units of the Armed Forces of Ukraine in the system of postgraduate education]. Zhytomyr Ivan Franko State university journal. Pedagogical sciences, 4 (95), 160-165.

5. Vysochina, N., Fedorenko, O., Vorona, V. (2019). Problems of physical training and sports in the Armed Forces of Ukraine. Black sea scientific journal of academic research, 46(3),4-9.

6. Romanchuk, S. (2015). Self-educational technologies of the commanders of cadets units of higher military educational institutionsin the field of physical training and sports. Journal of Physical Education and Sport, 15(3), 498-501.

7. Sergienko, Y., Andreianov, A. (2013). Model of professional readiness of students of higher military schools of the Armed Forces of Ukraine. Physical Education of Students, 6, 66-72.

8. Vysochina, N., Hunina, L., Khatsaiuk, O., Tomashevskyi, V., Tytovych, A. (2020). Vdoskonalennia profesiinykh kompetentnostei ofitseriv-fakhivtsiv fizychnoi pidhotovky i sportu u napriami vykorystannia suchasnykh interaktyvnykh pedahohichnykh tekhnolohii [Improving the professional competencies of officers-specialists in physical training and sports in the direction of using modern interactive pedagogical technologies]. Viiskova osvita, 2020. № 2, 76-88.

9. Kokun, O. M. (2012). Professional orientation and competence of future professionals with a "person-person" occupational type. Social Welfare. Interdisciplinary Approach, 2 (2), 36-47. 
10. Campos, F., Marques, M., Silva, S., Martins, F., Simoes, V., \& Franco, S. (2017). Physical self-description and sport participation, by gender, of university students. Journal of Physical Education and Sport, 17 (1), 207-211. DOI:10.7752/jpes.2017.01031

11. Hortigüela, D., Fernández-Río, J., Pérez-Pueyo, A. (2016). Long-term effects of the pedagogical approach on the perceptions of physical education by students and teachers. Journal of Physical Education and Sport, 16(4), 1326-1333. DOI:10.7752/jpes.2016.04210

12. Ilnytska, G., Kozina, Z., Kaвatska, O., Kostiukevych, V., Goncharenko, V., Bazilyuk, T., Al-rawashdeh, A. (2016). Impact of the combined use of health-improving fitness methods ("Pilates" and "Bodyflex") on the level of functional and psychophysiological capabilities of students. Journal of Physical Education and Sport, 16 (1), 234-240. DOI: 10.7752/jpes.2016.01037

13. Svystun, V. I., Shemchuk, V. A. (2018). Naukovo-doslidna laboratoriia yak orhanizator i koordynator innovatsiinoho naukovoho seredovyshcha vyshchoho viiskovoho navchalnoho zakladu [Scientific-research laboratory as the organizer and coordinator of the innovative scientific environment of the higher military educational institution]. Zhytomyr Ivan Franko State university journal. Pedagogical sciences, 4 (95), 182-187.

14. Petrachkov, O., Vysochina, N. (2019). The establishment of the Educational and scientific institute of physical culture and sports and health technologies of the National Defence University of Ukraine named after Ivan Chernyakhovskyi. Sporto mokslas, 1, 76-78. DOI: https://doi.org/10.15823/sm.2019.95

15. Kostiv, S. F. (2017). Emotsiino-volova stiikist maibutnikh viiskovykh fakhivtsiv. [Emotional-volitional stability of future military specialists]. Military education. Kiev, 2 (36), 107116.

16. Vysochina, N., Vorobiova, A. (2017). Goal-setting in sport and the algorithm of its realization. Ştiinţa culturii fizice, 28/2, 108-112.

\section{РЕЗЮМЕ}

Надежда Высочина, доктор наук по физическому воспитанию и спорту, старший исследователь

Учебно-научный институт физической культуры и спортивно-оздоровительных технологий

Национального университета обороны Украины имени ИванаЧерняховского

ORCID ID 0000-0001-6098-9699

Василий Белошицкий,

Учебно-научный институт физической культуры и спортивно-оздоровительных технологий Национального университета обороны Украины имени ИванаЧерняховского ORCID ID 0000-0001-6083-2579

Ольга Малахова,

Учебно-научный институт физической культуры и спортивно-оздоровительных технологий

Национального университета обороны Украины имени ИванаЧерняховского ORCID ID 0000-0002-9227-9234

\section{ФИЗИЧЕСКАЯ ПОДГОТОВКА И СПОРТ В ВООРУЖЕННЫХ СИЛАХ УКРАИНЫ: ПРОБЛЕМЫ И ПЕРСПЕКТИВЫ}

В статье рассмотрены актуальные проблемы физической подготовки и спорта в Вооруженных Силах Украины. Проанализировань причины и факторы, оказывающие 
негативное влияние на эффективность организации и управления процессом физической подготовки военнослужащих. Показаны пути решения проблем.

Физическая подготовка военнослужаших является неотъемлемой составной частью общей системы воспитания и обучения личного состава Вооруженных Сил Украины и других военных формирований сектора безопасности и обороны, образованных $в$ соответствии с законами Украины, и направлена на обеспечение физической готовности личного состава к профессиональной деятельности.

В связи с этим особую актуальность приобретает вопрос организации централизованной подготовки кадров по физической подготовке и спорту для структур сектора безопасности и оборонь Украины. Для решения этой проблемы Министерством обороны Украинь проводится системная работа по совершенствованию военного образования для ее адаптации к системе подготовки стран-членов НАТО и ЕС. Изучение опыта этих стран свидетельствует о тенденции централизации подготовки специалистов в сфере физической подготовки и спорта для Вооруженных Сил, правоохранительных органов и сочетание прочесса подготовки кадров с организаџией научных исследований.

Существующая система организащии физической подготовки и спорта в Вооруженных Силах Украины не в полной мере обеспечивает надлежащий уровень физической готовности военнослужащих к выполнению учебно-боевых задач, недостаточно побуждает военнослужаших к занятиям физической культурой и спортом, поддержанию здорового образа жизни, что негативно влияет на качество образовательного процесса подготовки курсантов и слушателей высших военных учебных заведений и на эффективность управления процессом физического совершенствования военнослужаших. Поэтому, внедрение предложенных рекомендаций позволит оптимизировать процесс физической подготовки военнослужащих.

Ключевые слова: Физическая подготовка и спорт, Вооруженные Силь Украины, здоровый образ жизни.

\section{SUMMARY}

Vysochina Nadiia,

Doctor of physical training and sport, senior researcher

Educational and Scientific Institute of Physical Culture and Sports and Health Technologies National defence university of Ukraine named after Ivan Cherniakhovskyi ORCID ID 0000-0001-6098-9699

Biloshytskyi Vasyl,

Educational and Scientific Institute of Physical Culture and Sports and Health Technologies National defence university of Ukraine named after Ivan Cherniakhovskyi ORCID ID 0000-0001-6083-2579

Malakhova Olha, Educational and Scientific Institute of Physical Culture and Sports and Health Technologies

National defence university of Ukraine named after Ivan Cherniakhovskyi ORCID ID 0000-0002-9227-9234

\section{THE PHYSICAL TRAINING AND SPORT IN THE ARMED FORCES OF UKRAINE: PROBLEMS AND PERSPECTIVES}

The article deals with topical issues of physical training and sports in Ukrainian Armed Forces. Analyzed the causes and factors that have a negative impact on the effectiveness of the 
organization and management of the process of physical training of military personnel. Showing solutions to problems.

Physical training of military personnel is an integral part of the general system of education and training of personnel of Ukrainian Armed Forces and other military units of the security and defense sector, established in accordance with the laws of Ukraine, and is aimed at ensuring the physical readiness of personnel for professional activities.

Due to this, the issue of organizing centralized training of personnel in physical culture and sport for the structures of the security and defence sector of Ukraine obtain a special relevance. To solve this problem, the Ministry of Defence of Ukraine is conducting systematic work to improve military education in order to adapt it to the training system of the North Atlantic Treaty Organization (next - NATO) and European Union(next - EU) member countries. Studying the experience of these countries demonstrates the tendency to centralize training of specialists in the field of physical training and sports for the Armed Forces, law enforcement agencies and the combination of the training process with the organization of scientific research.

The existing system of organization of physical training and sports in Ukrainian Armed Forces does not fully ensure an adequate level of physical readiness of military personnel to perform combat training tasks, does not sufficiently induce military personnel to engage in physical culture and sports, to maintain a healthy way of lifestyle, which negatively affects the quality of the educational process training of cadets and students of higher military educational institutions and on the effectiveness of managing the process of physical improvement of military employees. Therefore, the implementation of the proposed recommendations will optimize the process of physical training of military personnel.

Keywords: Physical training and sport, Ukrainian Armed Forces, a healthy lifestyle. 